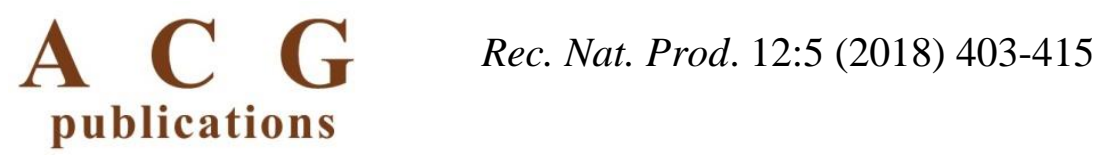

records of natural products

\title{
Management of Tobacco Mosaic Virus through Natural Metabolites
}

\author{
Waqar Islam $\odot^{\dagger 12^{*}}$, Muhammad Qasim $\odot^{\dagger 1}$, Ali Noman $\odot^{3,4}$, \\ Muhammad Tayyab $\odot^{3}$, Shiman Chen $\odot^{1}$ and Liande Wang $\odot^{1^{*}}$ \\ ${ }^{1}$ College of Plant Protection, Fujian Agriculture and Forestry University, Fuzhou-350002, China \\ ${ }^{2}$ Govt. of Punjab, Agriculture Department, Lahore, Pakistan \\ ${ }^{3}$ Department of Botany, Government College University, Faisalabad-38040, Pakistan \\ ${ }^{4}$ College of Crop Sciences, Fujian Agriculture and Forestry University, Fuzhou-350002, China
}

(Received October 30, 2017; Revised January 13, 2018; Accepted January 16, 2018)

\begin{abstract}
The viruses are one of the most threatening factors for plants resulting in gigantic economic losses. These utilize host internal machinery for reproduction and can spread through biological and non-biological means. Among the most hazardous plant viruses, Tobacco mosaic virus (TMV) is the most ancient virus which causes massive economic losses to tobacco, pepper, cucumber and ornamental crops globally. The problem can be reduced by minimizing the vector population through application of pesticides. Opposite to obtained success in virus control, rapid utilization of synthetic chemicals is disastrous for our ecosystem. Therefore, alternative approaches such as natural derivatives should be explored for eco-friendly management of TMV. So, here we have tried to take into account various natural metabolites which can be effectively and potentially used against TMV. We further explained about the derivatives from animals, fungi, bacteria and actinomycetes which are useful against TMV. The review imbibes the recent research findings regarding exploration of natural derivatives for management of TMV and concludes through highlighting the future prospects via hoping that future pesticides will be safer for human being and our planet.
\end{abstract}

Keywords: Alkaloids; tobacco mosaic virus; animals; microorganisms; plants. (C) 2018 ACG Publications. All rights reserved.

\section{Introduction}

Approximately $15 \%$ of global yield of economically important crops is being reduced every year by different plant diseases [1]. Plant viruses account for approximately $30 \%$ of plant diseases [2, 3]. These are nucleic acid based single stranded (ss) or double stranded (ds) DNA or RNA pathogens

\footnotetext{
${ }^{*}$ Corresponding author: E-Mail: wang liande@126.com (L.Wang); waqarislam@m.fafu.edu.cn (W.İslam)

$\uparrow$ These authors contributed equally to this article.
}

The article was published by ACG Publications

www.acgpubs.org/RNP @ September-October/2018 EISSN:1307-6167

DOI: http://doi.org/10.25135/rnp.49.17.10.178 
packed in proteins (capsids) which survive within the host via acquiring host internal machinery and further utilize it for the intracellular movements and transmission [3-5]. Viruses attacking plants are categorized as the second largest culprits causing huge losses to vegetables, house hold plants, ornamentals and various field crops worldwide i.e. approximately 60 billion USD in financial terms [6]. According to International committee of taxonomy of viruses (ICTV), there are 950 different types of plant viruses so far reported on our planet $[7,8]$.

TMV is the positive sensed single stranded (ss) RNA virus (Tobamovirus; Virgaviridae) producing mosaic"-like mottling discoloration symptoms on leaves. It is considered as the most ancient virus in plant virology as it was discovered in 1898 [9]. The particular virus causes massive damage to various crops including 125 plant species such as tobacco, cucumber, pepper and ornamentals [10]. TMV is a rod shaped virus with a capsid composed by 2130 coat protein (CP) molecules along with one ssRNA genomic molecule $(6.3-6.5 \mathrm{~kb})$ [11](Figure 1). The $\mathrm{CP}$ is selfassembled into the rod-like helical structure constituting 16.3 proteins per helix turn tight around the RNA forming a hairpin loop structure [12] TMV genome encodes 4 open reading frames (ORFs) [13] and is considered as thermo-stable virus tolerating up to $1200^{\circ} \mathrm{F}\left(50^{\circ} \mathrm{C}\right)$ up to 30 minutes with a refractive index of 1.57 [14].

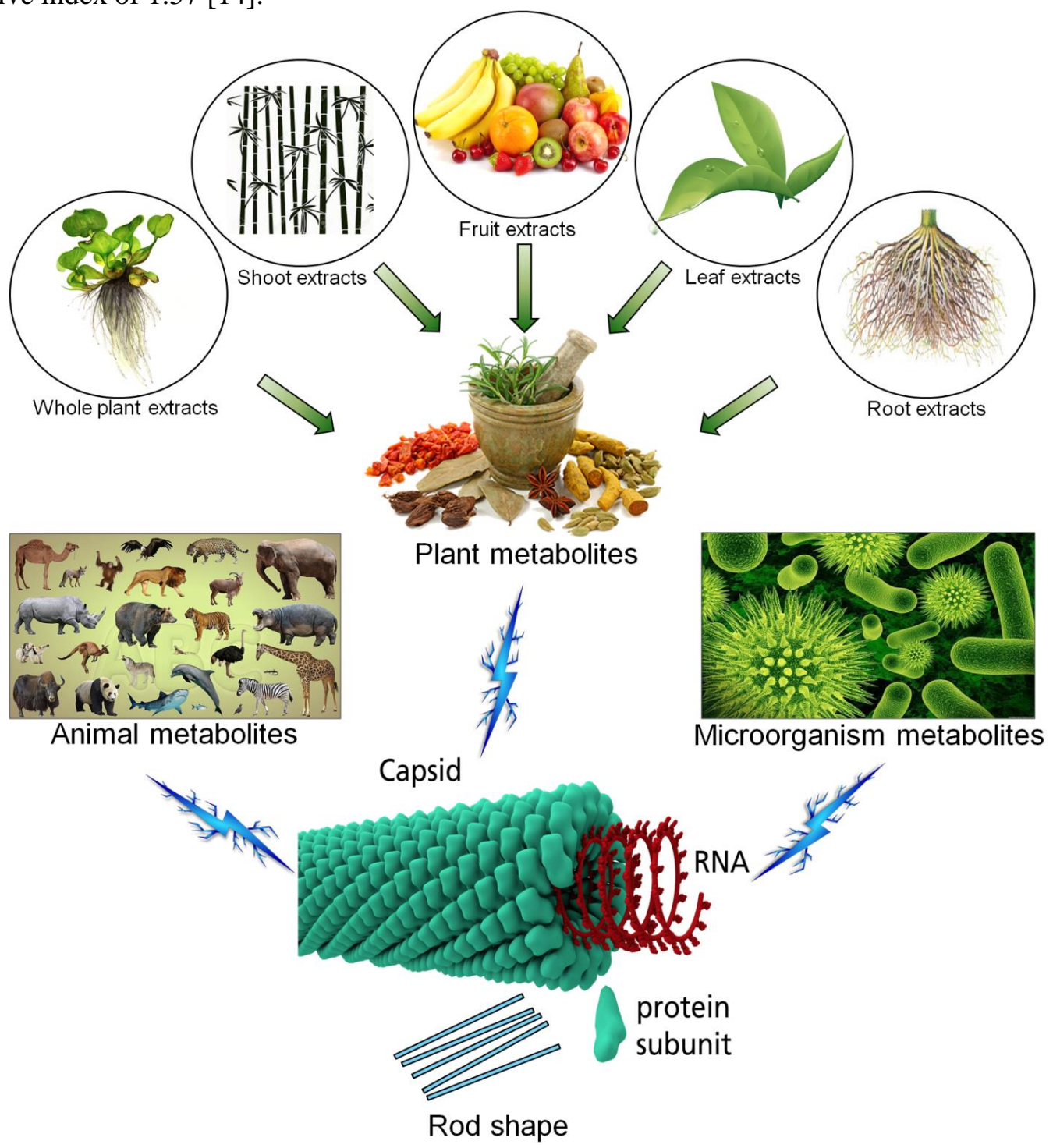

Figure 1. Structure of TMV and natural metabolites which have positive impacts against TMV 
Although impact of virus diseases can be reduced by minimizing the vector population by application of pesticides [8] but such treatments cannot completely eliminate the virus infections as they are not directly hitting upon the viruses [15]. Furthermore, pesticides have severe adverse effects upon human beings and our ecosystem [8,16-19]. For example, organophosphates and dichlorodiphenyltrichloroethane (DDT) which were launched in early 1930s for pest control against various pests proven severely lethal towards human health after their continuous usage of three decades [20-23]. Moreover, Carson extensively revealed about the injurious effects of synthetic chemicals towards human health and surrounding environment in his book named Silent spring [24]. Afterwards, awareness regarding preserving the ecosystem from pesticides and finding the alternatives enhanced rapidly. But the developing countries are yet not taking up the matter seriously. In the start of $21^{\text {st }}$ century, researchers focused to find the natural compounds which had the potential to be used as natural pesticides due to relatively less toxicity threat and least residual effects to surrounding environment [25-28]. Considering the environmental safety and human health, researchers shifted their thoughts towards the ancient times when people utilized the herbals and natural products for treatment of various infectious diseases. This led them towards the management of plant viruses through natural extracts from plants, animals and microorganisms [8, 29] through further commercialization of bio-pesticides [30]. These bio-pesticides are environmentally safer having least residual effects and more target specificity. Furthermore, these are not susceptible to viruses for attaining quick resistance against them thus encourage their large scale commercialization [30, 31]. This can be proved simply, as production of bio-products is increasing sixteen percent every year which is the three times more than synthetic pesticides i.e. 5.5\% per year [32]. Since 2001, researchers have made considerable progress in identification and evaluation of various plants, animal and microorganism based products against TMV as they have found several metabolites such as alkaloids, essential oils, flavonoids, phenols, polysaccharides and proteins [33-38]. So here we have reviewed about the research progress made in recent years regarding efficacy of plant metabolites against TMV. We further explained about the metabolites found in animals and microorganisms having anti TMV properties. We also have highlighted the important aspects, concerns and limitations via describing future prospects by hoping that upcoming pesticides utilization against TMV and other plant viruses will be safer for human beings and our ecosystem.

\section{Anti-TMV Metabolites from Plants}

Plant extracts always guide our thoughts on the basis of the historical utilization of herbs and herbal medicines for curing all type of human, mammalian and plant diseases [39-42]. In 1914, antiviral activity of pokeberry juice laid the research foundation for searching more plants with similar action [43]. Approximately, only $10 \%$ of 250,000 plants species on our planet [21] had been chemically characterized till the end of $20^{\text {th }}$ century [44]. These plants have played their vital role in human life through their industrial applications via providing nutrition, chemicals, medicines, cosmetics and much more [45]. Moreover, around 2400 plants have been successfully identified having anti-bio-organismic properties [46]. Whole plant extracts or extracts from different plant parts such as roots, shoots, leaves, bulbs, rhizomes and fruits have been found quite effective against various plant viruses (Figure 1; Table, 1). Correspondingly, looking into the history, Chinese herbals were very famous [47]. But in the beginning of this decade, researchers inspired to find the plant based extracts and products for their antiviral activities [48-50]. These efforts further clarified that plant based primary substances like proteins have better antiviral properties [51,52]. Similarly, 0.4 million secondary metabolic compounds i.e. alkaloids, anthocyanins, caratins, flavonoids, phenolics and certain type of oils, which play vital role during biotic and abiotic stresses, also have been found to have anti-bacterial, anti-fungal and antiviral characteristics $[79,80]$. These primary and secondary metabolites are commercially being utilized to synthesize various drugs to cure human, mammalian and plant diseases [30,31]. Some of these metabolites are actively being used in producing anti TMV bio-products, are explained here. 
Table 1. Natural metabolites and extracts which successfully inhibit TMV infection

\begin{tabular}{|c|c|c|c|c|c|c|}
\hline Name & Family & Organism & Extract / Metabolite & $\begin{array}{c}\text { \% TMV } \\
\text { inhibition }\end{array}$ & Concentration & Reference \\
\hline Celosia cristata $\mathrm{L}$. & Amaranthaceae & Plants & 7-deoxytrans-dihydronarciclasine & $>90$ & $20-30 \mu \mathrm{g} / \mathrm{mL}$ & {$[53]$} \\
\hline Cynanchum komarovii & Asclepiadaceae & Plants & Whole plant extract & 65 & $1.0 \mathrm{mg} / \mathrm{mL}$ & [54] \\
\hline Pleurotus citrinopileatus & $\underline{\text { Pleurotaceae }}$ & Fungi & Protein & 50 & $0.24 \mu \mathrm{g} / \mathrm{mL}$ & {$[55]$} \\
\hline Sambucus williamsii & $\overline{\text { Caprifoliaceae }}$ & Plants & $\begin{array}{l}\text { Essential oil and phenolic } \\
\text { compounds }\end{array}$ & 43 & -- & {$[56]$} \\
\hline Strobilanthes cusia & Acanthaceae & Plants & Leaf extract & 100 & $50 \mathrm{nM}$ & {$[34]$} \\
\hline Hosta plantaginea Aschers & Liliaceae & Plants & Whole plant extract & 91.4 & $50 \mu \mathrm{g} / \mathrm{mL}$ & [57] \\
\hline Bougainvillea xbuttiana & Nyctaginaceae & Plants & Protein, root extract & 94 & $50 \mu \mathrm{g} / \mathrm{mL}$ & {$[58]$} \\
\hline Brucea javanica (L.) Merr. & Simaroubaceae & Plants & Leaf extract & 78.9 & $200 \mathrm{mg} / \mathrm{L}$ & [59] \\
\hline Bacillus cereus & Bacillaceae & Bacteria & ZH14 & 94.2 & -- & {$[60]$} \\
\hline Picrasma quassioides & Simaroubaceae & Plants & Bruceine D & 60.4 & $50 \mu \mathrm{g} / \mathrm{mL}$ & [61] \\
\hline $\begin{array}{l}\text { Trichoderma pseudokoningii } \\
\text { SMF2 }\end{array}$ & Hypocreaceae & Fungus & Antimicrobial peptide & 54 & $100 \mathrm{nM}$ & {$[62]$} \\
\hline Sambucus williamsii & Caprifoliaceae & Plants & $\begin{array}{l}\text { Essential oil and phenolic } \\
\text { compounds }\end{array}$ & 34.3 & $1 \mathrm{mmol} / \mathrm{L}$ & {$[63]$} \\
\hline Lithospermum erythrorhizon & Boraginaceae & Plants & Bark extract & $63.6 \%$ & $2-10 \mu \mathrm{g} / \mathrm{mL}$ & [64] \\
\hline Munronia unifoliolata & Meliaceae & Plants & Protein & 64.2 & $30 \mu \mathrm{g} / \mathrm{mL}$ & {$[65]$} \\
\hline Rhodiola eurycarpa & Crassulaceae & Plants & Whole plant extracts & 54.55 & $10 \mu \mathrm{g} / \mathrm{mL}$ & [48] \\
\hline Achnatherum splendens & Poaceae & & Stem extracts & 60.36 & & \\
\hline Lactuca tatarica & Asclepiadaceae & & Whole plant extracts & 50.92 & & \\
\hline Syneilesis aconitifolia & Asclepiadaceae & & Whole plant extract & 71.67 & & \\
\hline Chaenomeles sinensis & Rosaceae & & Fruit extract & 94.57 & & \\
\hline Rubus flosculosus & Rosaceae & & Whole plant extract & 60.00 & & \\
\hline Thermopsis lanceolata & Leguminosae & & Leaf extract & 53.78 & & \\
\hline Cotinus coggygria & Anacardiaceae & & Leaf extract & 93.52 & & \\
\hline Rodgersia podophylla & Saxifragaceae & & Stem extract & 98.25 & & \\
\hline Pulsatilla chinensis & Ranunculaceae & & Leaf, root, stem extract & 61.25 & & \\
\hline Thlaspi arvense & Brassicaceae & & Whole plant extracts & 50.00 & & \\
\hline Rhodiola eurycarpa & Crassulaceae & & Whole plant extracts & 53.19 & & \\
\hline Achnatherum splendens & Poaceae & & Stem extracts & 60.39 & & \\
\hline Pseudomonas chlororaphis & $\underline{\text { Pseudomonadaceae }}$ & Bacteria & Peptide & 95 & $1 \mathrm{mg} / \mathrm{mL}$ & {$[66]$} \\
\hline Arundina graminifolia & Orchidaceae & Plants & Munronoids K & 48.2 & $20 \mu \mathrm{M}$ & [67] \\
\hline Zingiber officinale & Orchidaceae & Plants & Gramniphenol G & 50.00 & $100 \mu \mathrm{g} / \mathrm{mL}$ & {$[68]$} \\
\hline Chenopodium album & Chenopodiaceae & Plants & Leaf extract & 98.2 & $60 \mathrm{~g}$ & {$[69,70]$} \\
\hline Lentinus edodes & Marasmiaceae & Fungus & Lentinan & 83.2 & $10 \mu \mathrm{g} / \mathrm{mL}$ & [71] \\
\hline Cassia fistula & Papilionaceae & Plants & Whole plant extract & 31.3 & $32.2 \mathrm{mg}$ & [36] \\
\hline Momordica charantia & Cucurbitaceae & Plants & Protein & 67.21 & $500 \mu \mathrm{g} / \mathrm{mL}$ & [72] \\
\hline Eupatorium adenophorum & Asclepiadaceae & Plants & Fructo oligosaccharide & 79.69 & $50 \mathrm{mg} / \mathrm{mL}$ & [73] \\
\hline Pseudomonas fluorescens & $\underline{\text { Pseudomonadaceae }}$ & Bacteria & Protein & 88.3 & $\begin{array}{l}49.8 \times 10^{10} \\
\mathrm{cful} / \mathrm{mL}\end{array}$ & [74] \\
\hline Schisandra rubriflora & Schisandraceae & Plants & Whole plant extract & 78.00 & $0.15 \mathrm{mM}$ & {$[50]$} \\
\hline Coriolus versicolor & Polyporaceae & Fungus & Polysaccharide peptide & 71.5 & $500 \mu \mathrm{g} / \mathrm{mL}$ & [37] \\
\hline Cephalotaxus sinensis & $\overline{\text { Cephalotaxaceae }}$ & Plants & Drupacine and cephalotaxine & $\begin{array}{l}50.76- \\
53.41\end{array}$ & $100 \mu \mathrm{g} / \mathrm{mL}$ & [75] \\
\hline Boerhaavia diffusa & Nyctaginaceae & Plants & Root extracts & 100 & $0.2 \mathrm{mg} / \mathrm{mL}$ & [76] \\
\hline Phyllanthus emblica & $\overline{\text { Phyllanthaceae }}$ & Plants & $\begin{array}{l}\text { Root extracts } \\
\text { emblirol A (1) and B ( } 2\end{array}$ & $62.1-79.6$ & $1 \mathrm{mg} / \mathrm{mL}$ & {$[77]$} \\
\hline Tithonia diversifolia & $\underline{\text { Asteraceae }}$ & Plants & $\begin{array}{l}\text { Tagitinin C (Ses-2) and } 1 \beta \text { - } \\
\text { methoxydiversifolin-3-0-methyl } \\
\text { ether }\end{array}$ & $\begin{array}{c}60.27- \\
62.86\end{array}$ & $100 \mu \mathrm{g} / \mathrm{mL}$ & [78] \\
\hline
\end{tabular}




\subsection{Primary Metabolites}

Certain plant primary metabolites include polysaccharide carbohydrates, lipids and proteins. Of these, only polysaccharides and proteins have been noticed for their antiviral properties. The widely found plant polysaccharides have diverse biological functions [81-83]. These possess antiviral actions based upon their great target specificity, low residual effects and lower toxicity levels with broader action e.g. anti-aging, anti-cancer, anti-oxidation [71, 84-86]. Researchers have documented anti TMV performance of polysaccharides isolated from diverse plant species like Lycium barbarum [87], Chuanminshen violaceum [88], Caesalpinia ferrea [89], Achyranthes bidentata [90], Eupatorium adenophorum [73], Portulaca oleracea [91] and Astragalus propinquus [92]. Moreover, polysaccharides derived from root extracts of Arctium lappa appeared quite effective against TMV as it amplify the transcription levels of multiple defense related proteins (DRPs) and enzymes as compared to control treatment within 24 hours post inoculation [93].

On the other hand, the plant proteins are actually DRPs synthesized in response to the pathogen attack e.g. bacteria, fungi and viruses [94]. These DRPs are classified into 17 different families. Recently, beetin27 i.e. a DRP produced in response to virus attack in sugar beet (Beta vulgaris) leaves is believed to possess strong capacity against various phyto-pathogens as well. The protein like beetin27 also responds to the signals produced by salicyclic acid (SA), RNA polynucleotides and hydrogen per-oxide $\left(\mathrm{H}_{2} \mathrm{O}_{2}\right)$ generated due to viral infection [95,96]. Likewise, anti TMV properties due to DRPs productions have been observed in Bougainvillea xbuttiana [58]. In addition, some DRPs have also been identified in elderberry [56]. Correspondingly, DRPs i.e. CCP25 and CCP27 from Celosia cristata extracts also proved target specific and effective in minimizing TMV infections at a concentration of $30 \mu \mathrm{g} / \mathrm{mL}[53]$. Researchers have evaluated DRPs from Pokeweed with respect to their antiviral activity against human, mammalian as well as plant viruses like Human immune deficiency virus (HIV), Influenza virus, cytomegalovirus, TMV and several others. DRPs effectively suppress and inhibit virus replication [97$100]$.

\subsection{Secondary Metabolites}

Plant secondary metabolites include multiple kinds of substances involved in metabolism and also have anti-viral capacity [80]. These metabolites are alkaloids, essential oils, flavonoids and phenolics $[101,102]$. Pharmacological as well as medicinal effects of alkaloids on living organisms have been well documented. Alkaloids possess diverse structures having numerous bio active substances [103-105]. Ancient Chinese herbs reportedly possess 18000 alkaloids with anti-viral attributes [106]. Few years back, five diverse alkaloids were obtained from Hosta plantaginea and an alkaloid 7-deoxytransdihydronarciclasin was separated that exhibited anti-TMV activity even in least inhibitory concentration i.e. $1.80 \mu \mathrm{M}$ [57]. In the same way, Brucea javanica extract have Bruceine-D displaying inhibitory effects against TMV [59]. Likewise, 17 quassinoids with anti TMV infection characteristics were identified having 3.42-5.66 $\mu \mathrm{M}$ IC50 value [107]. Chen and his fellow researchers [61] investigated Picrasma quassioides wood extract for anti TMV activities. They identified some $\beta$-carboline alkaloids and a quassinoid with moderately positive results. Furthermore, the extracts revealed synergetic effects when applied in combination with nigakilactone $B$. The combined supplement of these alkaloids and quassinoid improved the inhibition from 36.4 to $68.4 \%$. Similarly, An et al. [54] explained about Cynanchum komarovii derivatives embedding two alkaloids (7-demethoxytylophorine and 7-demethoxytylophorine $\mathrm{N}$ oxide) with approximately 60 and $65 \%$ anti TMV activity at a concentration of $500 \mu \mathrm{g} / \mathrm{mLand} 1.0 \mu \mathrm{g} / \mathrm{mL}$.

Essential oils are complex mixtures of lower molecular weight [108, 109]. Utilization and processing of essential oils have exponentially increased over the years [110]. They are normally used in cosmetics, drinks, food flavors and perfumes [111]. These oils can be found in resin ducts, various glands and oil ducts inside plant body [112]. Besides, these oils show anti-bacterial, anti-fungal, anti-insects and anti-viral characteristics [113]. It is interesting to note that over 50\% TMV inhibition was observed when essential oils from ginger, lemon, tea tree, tangerine peel, artemisia and lemongrass were applied at a 
concentration of $100 \mu \mathrm{g} / \mathrm{mL}[68,114]$. Equally, essential oils i.e. carvacrol and thymol from Satureja montana performed $34.3 \%$ suppressing activity against TMV at $2 \mathrm{mmol} / \mathrm{L}$ concentrations [63]. Talking about flavonoids extracted from herbs reveals interesting facts [115]. It is estimated that approximately 10000 flavonoids are on record [116]. For their antiviral roles, 28.5\% and 31.3\% TMV repression was recorded by fistula $B$ and fistula $C$ from Cassia fistula at a concentration of $20 \mu \mathrm{M} \mathrm{[36].}$

Phenolics also have anti-viral characteristics [117], and their higher concentration have been reported in tea, cottons seeds and other medicinal plants [114, 118, 119]. Phenolics further include important compounds like anthocyanins, ellagitannins, hydroxycinnamates and procyanidins [120]. Arundina gramnifolia possess three diverse phenolics (Gramniphenol $C$, Gramniphenol $F$ and Gramniphenol $G$ ). These compounds have respectively shown 48.2, 35.8 and 32.1 percent TMV inhibition after application at $20 \mu \mathrm{M}$ concentration [67]. In addition, gossypol from cotton seed presented up to 54.4\% TMV inhibition with concentration of $500 \mu \mathrm{g} / \mathrm{mL}$ [38]. These data supported in commercial development of anti TMV product called Zai-xi-chun containing active gossypol and several other bio components. Likewise, another commercial anti-viral bio-product (Ningnanmycin) has now been improved after addition of Schisandra rubriflora extract possessing phenol called schisanhenol. This new composition presented 78.00-83.5\% inhibition of TMV [50].

\section{Anti-TMV Metabolites from Animals}

Majority of animal metabolites with anti-plant virus activities have not been much explored. However, it is documented that a couple of oligosaccharides such as chitin and chitosan have anti-plant virus characteristics [81]. These are hydrolysed products from chitosan polymers which have potential to activate plant defenses against invading viruses [121]. Particularly against TMV, chitosan have been found to have $50.41 \%$ inhibition rate at a concentration of $50 \mu \mathrm{g} / \mathrm{mL}[122]$. Further exploring the chitosan, researchers have found that chitosan inhibitory effects are modulated via production of nitric oxide, hydrogen peroxide, protein kinase, phenylalanine ammonia-lyase activity and co-regulated through a signaling pathway i.e. $\mathrm{Ca}^{2+}[123-127]$.

\section{Anti-TMV Metabolites from Micro-organisms}

These may include various pathogenic and non-pathogenic organisms such as actinomycetes, algae, bacteria and fungi. Anti-TMV metabolites from these organisms have been explained further. Various peptides, proteins and polysacccharaides are the famous metabolites found in various fungi which have anti-viral properties [128,129]. Extracts from Coriolus versicolor, Coprinus comatus, Lentinus edodes, Pleurotus ostreatus, Flammulina velutiper and several other fungi have been characterized to have anti TMV properties (Table 1). For fungal polysaccharides from Coriolus versicolor, it has been observed that the particular polysaccharide exhibits 85.4\% inhibition @ $500 \mu \mathrm{g} / \mathrm{mLconcentration}$ while the inhibition rate of the disease was reduced to $64.8 \%$ at $100 \mu \mathrm{g} / \mathrm{mLconcentration,} \mathrm{respectively} \mathrm{[37].}$ Exploiting the same fungus, another metabolite called Lentinan recorded 58.7\% TMV inhibition at an application of $10 \mu \mathrm{g} / \mathrm{mLconcentration} \mathrm{[71].} \mathrm{Researchers} \mathrm{has} \mathrm{explained} \mathrm{that} \mathrm{Lentinan} \mathrm{actively} \mathrm{increase} \mathrm{the}$ anti TMV tolerance in plants via increasing the host plant resistance by generating per oxides and DRPs [37, 130, 131]. In a similar context, some bacterial metabolites have been recently found to have anti TMV properties. For example, ZH14 bacterial strain which produces some proteins, have inhibitory effects against TMV infection [60]. Similarly, various strains from pseudomonas have anti TMV properties [66,74]. Moreover, Actinomycetes which have great importance regarding commercial production of medicines [132,133] also have anti-plant virus characteristics such as Ningnanmycin extracted from Strepcomces noursei [134] and Cytosinpeptidemycin isolated from Streptomyces ahygroscopicus [135, 136]. Further investigating these two metabolites clarified that Ningnanmycin inhibited TMV infection up to $58.1 \%$ when applied at a concentration of $500 \mu \mathrm{g} / \mathrm{mL}$ [38] while Cytosinpeptidemycin showed 80\% TMV infection inhibition at the concentration of $1 \mathrm{mg} / \mathrm{mL}[137]$. 


\section{Conclusion and Future Prospects}

Although plant virus diseases results in gigantic economic losses worldwide but it is still not fair to apply synthetic chemicals for minimizing their impact upon global agriculture. To cope with the situation and to find alternative anti-viral substances, it is more feasible to search the natural sources of least residual effects along with overwhelming anti-viral activities. Although, we have witnessed an increased rate of commercialization of bio-products but when we talk specifically about anti TMV bioproducts, we find only few efforts made in this research field. Metabolites from plants, animals and micro-organisms can be utilized to prepare commercial bio-products and limitations and constraints must be reduced. It is not easy to obtain natural extracts directly as several technical themes are necessary to fulfill for their effective preparation and formulation [8,138]. International federation of organic agriculture movements (IFOAM) standards must be followed for extraction of any active ingredient from natural herbs [139]. We have witnessed that higher concentration of natural extracts are normally required for quick and efficient minimization of TMV infection thus requiring the larger population of herbs, animals or micro-organisms locally can be challenging sometimes. To address this problem, particular organisms should be isolated and their population should be increased via breeding strategies. Similarly, complete characterization of anti TMV natural metabolites has not yet been achieved. Researchers must maintain a gene pool regarding all anti TMV metabolites. Such characterization is also necessary for the insect vectors. Therefore, rapid screening of natural metabolites should be carried out regarding their antivirus-host interaction effects. Likely screening efforts will amplify the research regarding structural and functional relationships among the several primary and secondary active components in natural extracts. Detailed analyses and utilization of these substances will open new horizons in finding the similar components in marine, fossils and algal communities. Finally, we recommend accelerated field experimentation regarding efficacy of natural metabolites to identify plant species with new anti-viral properties. We believe that future pesticides will be safer for human health as well as for our ecosystem.

\section{ORCID}

Waqar Islam: 0000-0002-2383-402X

Muhammad Qasim: 0000-0002-8063-9140

Ali Noman: 0000-0002-4159-199X

Muhammad Tayyab: 0000-0003-3051-3133

Shiman Chen: 0000-0002-4190-997X

Liande Wang:0000-0001-8395-7243

\section{References}

[1] R. Cerda, J. Avelino, C. Gary, P. Tixier, E. Lechevallier and C. Allinne (2017). Primary and secondary yield losses caused by pests and diseases: Assessment and modeling in coffee, PloS one. 12, e0169133.

[2] A. Boualem, C. Dogimont and A. Bendahmane (2016). The battle for survival between viruses and their host plants, Curr. Opin. Virol. 17, 32-38.

[3] W. Islam, M. Zaynab, M. Qasim and Z. Wu (2017). Plant-virus interactions: Disease resistance in focus, Hosts Viruses. 4, 5-20.

[4] W. Islam and Z. Wu (2017). Genetic defense approaches against begomoviruses. J. Appl. Virol. 6, 26-49.

[5] M. Arif, W. Lin, L. Lin, W. Islam, Z. Jie, Z. He, Z. Du and Z. Wu (2017). Cotton leaf curl Multan virus infecting Hibiscus sabdariffa in China, Can. J. Plant Pathol. 1-4.

[6] K.O. Afolabi, B.C. Iweriebor, A.I. Okoh and L.C. Obi (2017). Global status of porcine circovirus type 2 and its associated diseases in sub-saharan Africa, Adv. Virol. 2017, Article ID 6807964. 
[7] J.K. Brown, C.M. Fauquet, R.W. Briddon, M. Zerbini, E. Moriones, J. Navas-Castillo, A.M.Q King, M.J. Adams, E.B. Carstens and E.J. Lefkowitz (2012). The single stranded dna viruses, Geminiviridae. In; Virus taxonomy - ninth report of the International Committee on Taxonomy of Viruses. 351-373.

[8] W. Islam, J. Zhang, M. Adnan, A. Noman, M. Zainab and Wu. Z (2017). Plant virus ecology: a glimpse of recent accomplishments, Appl. Econ. Environ. Res. 15, 691-705.

[9] M.W. Beijerinck (1898). Über ein contagium vivum fluidum als Ursache der Fleckenkrankheit der Tabaksblätter, Müller, p. 3-24.

[10] Y. Yang and D.F. Klessig (1996). Isolation and characterization of a tobacco mosaic virus-inducible myb oncogene homolog from tobacco, Proc. Nat. Acad. Sci. 93, 14972-14977.

[11] D-J. Hwang, I.M. Roberts and T.M.A. Wilson (1994). Assembly of tobacco mosaic virus and TMV-like pseudovirus particles in Escherichia coli. In Positive-Strand RNA Viruses, Springer, 543-558.

[12] L. Stryer, J. Berg, J. Tymoczko and N. Clarke (1988). Biochemistry New York. Spectrum.

[13] R.C. Gergerich and V.V. Dolja (2006). Introduction to plant viruses, the invisible foe, Plant Health Instructor. 19, 1-11.

[14] A. Ashkin. and J.M. Dziedzic (1987). Optical trapping and manipulation of viruses and bacteria, Science 235, 1517-1521.

[15] P. Schreinemachers, S. Balasubramaniam, N.M. Boopathi, C.V. Ha, L. Kenyon, S. Praneetvatakul, A. Sirijinda, N.T. Le, R. Srinivasan and M-H. Wu (2015). Farmers' perceptions and management of plant viruses in vegetables and legumes in tropical and subtropical Asia, Crop Protec. 75, 115-123.

[16] W. Islam and M. Ahmed (2016). Inhibitory effects of organic extracts against Aspergilus flavus and their comparative efficacy upon germination of infested rice seeds, PSM Microbiol. 1, 79-84.

[17] W. Islam, M. Awais, A. Noman and Z. Wu (2016). Success of bio products against bacterial leaf blight disease of rice caused by Xanthomonas oryzae pv. oryzae, PSM Microbiol. 1, 50-55.

[18] M. Tayyab, A. Noman, W. Islam, S. Waheed, Y. Arafat, F. Ali, M. Zaynab, S. Lin, H. Zhang and W. Lin (2018). Bioethanol production from Lignocellulosic biomass by environment-friendly pretreatment methods: a review, Appl. Ecol. Env. Res. 16, 225-249.

[19] A. Idrees, H. Zhang, M. Luo, M. Thu, P. Cai, W. Islam, M. Hussain, J. Chen and Q. Ji (2017). Protein baits, volatile compounds and irradiation influence the expression profiles of odorant-binding protein genes in Bactrocera dorsalis (Diptera: Tephritidae), Appl. Ecol. Env. Res. 15, 1883-1899.

[20] T. Slootweg, M. Alvinerie, P. Egeler, D. Gilberg, J.V.K. Kukkonen, J. Oehlmann, C. Prasse, A.J. Sormunen and M. Liebig (2010). Bioaccumulation of ivermectin from natural and artificial sediments in the benthic organism Lumbriculus variegatus, J. Soils Sedimen. 10, 1611-1622.

[21] L. Zhao, C. Feng, K. Wu, W. Chen, Y. Chen, X. Hao and Y. Wu (2017). Advances and prospects in biogenic substances against plant virus: A review, Pestic. Biochem. Physiol. 135, 15-26.

[22] M. Arshad, S. Ali, A. Noman, Q. Ali, M. Rizwan, M. Farid and M.K. Irshad (2016). Phosphorus amendment decreased cadmium $(\mathrm{Cd})$ uptake and ameliorates chlorophyll contents, gas exchange attributes, antioxidants, and mineral nutrients in wheat (Triticum aestivum L.) under Cd stress, Arch. Agron. Soil Sci. 62, 533-546.

[23] A. Noman, M. Aqeel, M.T. Javed, S. Zafar, Q. Ali, W. Islam, M.K. Irshad, M. Buriro, H. Kanwal and N. Khalid (2017). Histological changes in Hibiscus rosa-sinensis endorse acclimation and phytoremediation of industrially polluted sites, J. Anim. Plant Sci. 27, 1637-1648.

[24] R. Carson (1994). Silent spring. 1962. Houghton Mifflin Company; Anniversary edition (2002 and 2012). 0618249060 .

[25] D. Pimentel and M. Burgess (2014). Environmental and economic costs of the application of pesticides primarily in the United States. In Integrated pest management, Springer, 47-71.

[26] H. Ali, M. Qasim, H.S.A Saqib, M. Arif and S-U. Islam (2015). Synergetic effects of various plant extracts as bio-pesticide against wheat aphid (Diurophous noxia L.)(Hemiptera: Aphididae), Afr. J. Agric. Sci. Technol. 3, 310-315.

[27] A. Idrees, M. Qasim, H. Ali, Z.A. Qadir, A. Idrees, M.H. Bashir and Q. Ji (2016). Acaricidal potential of some botanicals against the stored grain mites, Rhizoglyphus tritici, J. Entomol. Zool. Stud. 4, 611-617.

[28] S. Kumar (2014). Plant disease management in India: Advances and challenges, Afric. J. Agric. Res. 9, 12071217.

[29] A.H.C. van Bruggen, A. Gamliel and M.R. Finckh (2016). Plant disease management in organic farming systems, Pest Manag. Sci. 72, 30-44. 
[30] D. Chandler, A.S. Bailey, G.M. Tatchell, G. Davidson, J. Greaves and W.P. Grant (2011). The development, regulation and use of biopesticides for integrated pest management, Philos. Trans. R. Soc. Lond., B, Biol. Sci. 366, 1987-1998.

[31] S. Kumar (2012). Biopesticides: a need for food and environmental safety, J. Biofertil. Biopestic. 3, $1000 \mathrm{e} 1107$.

[32] P.G. Marrone, P. Himmel and A. Stewart (2013). Market opportunities for biopesticides. In American Chemical Society, 246 ${ }^{\text {th }}$ National Meeting and Exposition. Picogram, 84, p. 104.

[33] N. Shibuya and E. Minami (2001). Oligosaccharide signalling for defence responses in plant, Physiol. Mol. Plant Pathol. 59, 223-233.

[34] Y. Li, L. Wang, S. Li, X. Chen, Y. Shen, Z. Zhang, H. He, W. Xu, Y. Shu and G. Liang (2007). Secopregnane steroids target the subgenomic RNA of alphavirus-like RNA viruses, Proc. Nat. Acad. Sci. 104, 8083-8088.

[35] S. Miresmailli and M.B. Isman (2014). Botanical insecticides inspired by plant-herbivore chemical interactions, Trend. Plant Sci. 19, 29-35.

[36] W. Zhao, X. Zeng, T. Zhang, L. Wang, G. Yang, Y-K. Chen, Q. Hu and M. Miao (2013). Flavonoids from the bark and stems of Cassia fistula and their anti-tobacco mosaic virus activities, Phytochem. Lett. 6, 179-182.

[37] L. Zhao, X. Hao and Y. Wu (2015). Inhibitory effect of polysaccharide peptide (PSP) against Tobacco mosaic virus (TMV), Int. J. Biol. Macromol. 75, 474-478.

[38] L. Zhao, C. Feng, C. Hou, L. Hu, Q. Wang and Y. Wu (2015). First discovery of acetone extract from cottonseed oil sludge as a novel antiviral agent against plant viruses, PloS one. 10, e0117496.

[39] M.M. Cowan (1999). Plant products as antimicrobial agents, Clin. Microbiol. Rev. 12, 564-582.

[40] K.B. Pandey and S.I. Rizvi (2009). Plant polyphenols as dietary antioxidants in human health and disease, Oxid. Med. Cell Longev. 2, 270-278.

[41] A. Noman, I. Hussain, Q. Ali, M.A. Ashraf and M.Z. Haider (2013). Ethnobotanical studies of potential wild medicinal plants of Ormara, Gawadar, Pakistan, Emirates J. Food Agric. 25, 751.

[42] A. Noman, M. Aqeel, S. Khan, S. Anwer and Q. Ali (2017). Exploration of medicinal phytodiversity at Makran coast; a realm of opportunities and challenges, Soil Biol. Biochem. 42, 177-190.

[43] G. Silber and L. Burk (1965). Infectivity of tobacco mosaic virus stored for fifty years in extracted, 'unpreserved'plant juice, Nature. 206, 740-741.

[44] D.S. Duarte, M.F. Dolabela, C.E. Salas, D.S. Raslan, A.B. Oliveiras, A. Nenninger, B. Wiedemann, H. Wagner, J. Lombardi and M.T.P. Lopes (2000). Chemical characterization and biological activity of Macfadyena unguis-cati (Bignoniaceae), J. Pharm. Pharmacol. 52, 347-352.

[45] J. Salimon, N. Salih and E. Yousif (2012). Industrial development and applications of plant oils and their biobased oleochemicals, Arab. J. Chem. 5, 135-145.

[46] D. Ndjonka, L.N. Rapado, A.M. Silber, E. Liebau and C. Wrenger (2013). Natural products as a source for treating neglected parasitic diseases, Int. J. Mol. Sci. 14, 3395-3439.

[47] B.B. Petrovska (2012). Historical review of medicinal plants' usage, Pharmacognosy Rev. 6, 1-5.

[48] B. Jing, Z. Ma, J. Feng, H. Liang, C. Li and X. Zhang (2012). Evaluation of the antiviral activity of extracts from plants grown in the qinling region of China against infection by Tobacco mosaic virus (TMV), J. Phytopathol. 160, 181-186.

[49] E.K.F. Elbeshehy, E.M.R. Metwali and O.A. Almaghrabi (2015). Antiviral activity of Thuja orientalis extracts against watermelon mosaic virus (WMV) on Citrullus lanatus, Saudi J. Biol. Sci. 22, 211-219.

[50] Q-Y. Wang, L-L. Deng, J-J. Liu, J-X. Zhang, X-J. Hao and S-Z. Mu (2015). Schisanhenol derivatives and their biological evaluation against tobacco mosaic virus (TMV), Fitoterapia. 101, 117-124.

[51] M.A. Al-Yahya (2005). Preliminary phytochemical and pharmacological studies on the rind of pomegranate (Punica granatum L.), Pak. J. Biol. Sci. 8, 479-481.

[52] S.W. Hassan, F.L. Bilbis, M.J. Ladan, R.A. Umar, S.M. Dangoggo, Y. Saidu, M.K. Abubakar and U.Z. Faruk (2006). Evaluation of antifungal activity and phtochemical analysis of leaves, roots and stem barks extracts of Calotropis procera (Asclepiadaceae), Pak. J. Biol. Sci. 9, 2624-2629.

[53] A. Balasubrahmanyam, V.K. Baranwal, M.L. Lodha, A. Varma and H.C. Kapoor (2000). Purification and properties of growth stage-dependent antiviral proteins from the leaves of Celosia cristata, Plant Sci. 154, 13-21.

[54] T-Y. An, R-Q. Huang, Z. Yang, D-K. Zhang, G-R. Li, Y-C. Yao and J. Gao (2001). Alkaloids from Cynanchum komarovii with inhibitory activity against the tobacco mosaic virus, Phytochem. 58, 1267-1269. 
[55] M.J. Fu, Z.J. Wu, Q.Y. Lin and L.H. Xie (2002). Purification of a antiviral protein in Plearotus citrinopileatus and its activities against tobacco mosaic virus and Hepatitis B virus, Virol. Sin. 17, 350-353.

[56] F. Vandenbussche, S. Desmyter, M. Ciani, P. Proost, W.J. Peumans and E.J.M. Van Damme (2004). Analysis of the in planta antiviral activity of elderberry ribosome-inactivating proteins, The FEBS J. 271, 1508-1515.

[57] Y-H. Wang, Z-K. Zhang, F-M. Yang, Q-Y. Sun, H-P. He, Y-T. Di, S-Z. Mu, Y. Lu, Y. Chang and Q-T. Zheng (2007). Benzylphenethylamine alkaloids from Hosta plantaginea with inhibitory activity against tobacco mosaic virus and acetylcholinesterase, J. Nat. Prod. 70, 1458-1461.

[58] N. Choudhary, H.C. Kapoor and M.L. Lodha (2008). Cloning and expression of antiviral/ribosomeinactivating protein from Bougainvillea xbuttiana, J. BioSci. 33, 91-101.

[59] J-G. Shen, Z-K. Zhang, Z-J. Wu, M-A. Ouyang, L-H. Xie and Q-Y. Lin (2008). Antiphytoviral activity of bruceine-D from Brucea javanica seeds, Pest Manag. Sci. 64, 191-196.

[60] W-W. Zhou, L-X. Zhang, B. Zhang, F. Wang, Z-H. Liang and T-G. Niu (2008). Isolation and characterization of ZH14 with antiviral activity against Tobacco mosaic virus, Can. J. Microbiol. 54, 441-449.

[61] J. Chen, X-H. Yan, J-H. Dong, P. Sang, X. Fang, Y-T. Di, Z-K. Zhang and X-J. Hao (2009). Tobacco mosaic virus (TMV) inhibitors from Picrasma quassioides Benn, J. Agric. Food Chem. 57, 6590-6595.

[62] Y. Luo, D-D. Zhang, X-W. Dong, P-B. Zhao, L-L. Chen, X-Y. Song, X-J. Wang, X-L. Chen, M. Shi and Y-Z. Zhang (2010). Antimicrobial peptaibols induce defense responses and systemic resistance in tobacco against tobacco mosaic virus, FEMS Microbiol. Lett. 313, 120-126.

[63] V. Dunkić, N. Bezić, E. Vuko and D. Cukrov (2010). Antiphytoviral activity of Satureja montana L. ssp. variegata (Host) PW ball essential oil and phenol compounds on CMV and TMV, Molecules. 15, 6713-6721.

[64] S-S. Chen, J. Lin, Q-B. Chen, Y-F. Liu, L. Ma, C-J. Li and X-D. Ma (2012). Quantitative estimation of the effects of propionylshikonin on the binding of TMV RNA and tobacco mRNA to wheat germ ribosome in vitro, Pestic. Biochem. Physiol. 103, 135-143.

[65] Y-H. Ge, K-X. Liu, J-X. Zhang, S-Z. Mu and X-J. Hao (2012). The limonoids and their antitobacco mosaic virus (TMV) activities from Munronia unifoliolata Oliv, J. Agric. Food Chem, 60, 4289-4295.

[66] J.Y. Park, S.Y. Yang, Y.C. Kim, J-C. Kim, Q. Le Dang, J.J. Kim and I.S. Kim (2012). Antiviral peptide from Pseudomonas chlororaphis $\mathrm{O6}$ against tobacco mosaic virus (TMV), J. Korean Soc. Appl. Biol. Chem. 55, 89-94.

[67] Q-F. Hu, B. Zhou, J-M. Huang, X-M. Gao, L-D. Shu, G-Y. Yang and C-T. Che (2013). Antiviral phenolic compounds from Arundina gramnifolia, J. Nat. Prod. 76, 292-296.

[68] M. Lu, Z.Q. Han, Y. Xu and L. Yao (2013). In vitro and in vivo anti-tobacco mosaic virus activities of essential oils and individual compounds, J. Microbiol. Biotechnol. 23, 771-778.

[69] S. Dutt, S. Narwal, H.C. Kapoor and M.L. Lodha (2003). Isolation and characterization of two protein isoforms with antiviral activity from Chenopodium album L leaves, J. Plant Biochem. Biotechnol. 12, 117122.

[70] S.P. Choudhary and D.K. Sharma (2014). Bioactive constituents, phytochemical and pharmacological properties of Chenopodium album: a miracle weed, Int. J. Pharmacogn, 1. 545-552.

[71] J. Wang, H-Y. Wang, X-M. Xia, P-P. Li and K-Y. Wang (2013). Inhibitory effect of sulfated lentinan and lentinan against tobacco mosaic virus (TMV) in tobacco seedlings, Int. J. Biol. Macromol. 61, 264-269.

[72] F. Zhu, P. Zhang, Y-F. Meng, F. Xu, D-W. Zhang, J. Cheng, H-H. Lin and D-H. Xi (2013). Alphamomorcharin, a RIP produced by bitter melon, enhances defense response in tobacco plants against diverse plant viruses and shows antifungal activity in vitro, Planta. 237, 77-88.

[73] Y. Jin, Y. Zhang, C. Wan, H. Wang, L. Hou, J. Chang, K. Fan and X. Xie (2013). Immunomodulatory activity and protective effects of polysaccharide from Eupatorium adenophorum leaf extract on highly pathogenic H5N1 influenza infection, Evid. Based Complement. Alternat. Med. 2013, Article ID 194976.

[74] L. Shen, F. Wang, J. Yang, Y. Qian, X. Dong and H. Zhan (2014). Control of tobacco mosaic virus by Pseudomonas fluorescens $\mathrm{CZ}$ powder in greenhouses and the field, Crop Protec. 56, 87-90.

[75] S. Ma, X. Shi, H. Yan, Z. Ma and X. Zhang (2016). Antiphytoviral activity of alkaloids from Cephalotaxus sinensis, Ind. Crops Prod. 94, 658-664.

[76] L.P. Awasthi, H.N. Verma and S. Kluge (2016). A Possible mechanism of action for the inhibition of plant viruses by an antiviral glycoprotein isolated from Boerhaavia diffusa roots, J. Virol. Antivir. Res. 5, 1000159.

[77] H. Yan, L.R. Han, X. Zhang and J.T. Feng (2017). Two new Anti-TMV active chalconoid analogues from the root of Phyllanthus emblica, Nat. Prod. Res. 31, 2143-2148. 
[78] L. Zhao, J. Dong, Z. Hu, S. Li, X. Su, J. Zhang, Y. Yin, T. Xu, Z. Zhang and H. Chen (2017). Anti-TMV activity and functional mechanisms of two sesquiterpenoids isolated from Tithonia diversifolia, Pestic. Biochem. Physiol. 140, 24-29.

[79] N. Krishnan, S. Ramanathan, S. Sasidharan, V. Murugaiyah and S.M. Mansor (2010). Antimicrobial activity evaluation of Cassia spectabilis leaf extracts, IJP-Int. J. Pharmacol. 6, 510-514.

[80] M. Wink (2015). Modes of action of herbal medicines and plant secondary metabolites, Medicines. 2, 251286.

[81] W. Wang, S-X. Wang and H-S. Guan (2012). The antiviral activities and mechanisms of marine polysaccharides: an overview, Marine Drugs. 10, 2795-2816.

[82] A. Ahmadi, S.Z. Moghadamtousi, S. Abubakar and K. Zandi (2015). Antiviral potential of algae polysaccharides isolated from marine sources: a review, BioMed Res. Int. 2015, Article ID 825203.

[83] M.C. Minari, V.P. Rincão, S.A. Soares, N.M. Ricardo, C. Nozawa and R.E. Linhares (2011). Antiviral properties of polysaccharides from Agaricus brasiliensis in the replication of bovine herpesvirus 1, Acta Virol. 55, 255-259.

[84] V.D. Prajapati, P.M. Maheriya, G.K. Jani and H.K. Solanki (2014). Carrageenan: a natural seaweed polysaccharide and its applications, Carbohydr. Polym. 105, 97-112.

[85] X. Chen, Y. Fang, K. Nishinari, H. We, C. Sun, J. Li and Y. Jiang (2014). Physicochemical characteristics of polysaccharide conjugates prepared from fresh tea leaves and their improving impaired glucose tolerance, Carbohydr. Polym. 112, 77-84.

[86] V.K. Thakur and M.K. Thakur (2014). Recent trends in hydrogels based on Psyllium polysaccharide: a review, J. Clean. Prod. 82, 1-15.

[87] J. Wang, Y. Hu, D. Wang, F. Zhang, X. Zhao, S. Abula, Y. Fan and L. Guo (2010). Lycium barbarum polysaccharide inhibits the infectivity of Newcastle disease virus to chicken embryo fibroblast, Int. J. Biol. Macromol. 46, 212-216.

[88] X. Song, Z. Yin, L. Li, A. Cheng, R. Jia, J. Xu, Y. Wang, X. Yao, C. Lv and X. Zhao (2013). Antiviral activity of sulfated Chuanminshen violaceum polysaccharide against duck enteritis virus in vitro, Antiviral Res. 98, 344-351.

[89] N. Lopes, L.C. Faccin-Galhardi, S.F. Espada, A.C. Pacheco, N.M.P.S. Ricardo, R.E.C. Linhares and C. Nozawa (2013). Sulfated polysaccharide of Caesalpinia ferrea inhibits herpes simplex virus and poliovirus, Int. J. Biol. Macromol. 60, 93-99.

[90] C. Liu, H. Chen, K. Chen, Y. Gao, S. Gao, X. Liu and J. Li (2013). Sulfated modification can enhance antiviral activities of Achyranthes bidentata polysaccharide against porcine reproductive and respiratory syndrome virus (PRRSV) in vitro, Int. J. Biol. Macromol. 52, 21-24.

[91] C-X. Dong, K. Hayashi, J-B. Lee and T. Hayashi (2010). Characterization of structures and antiviral effects of polysaccharides from Portulaca oleracea L., Chem. Pharm. Bull. 58, 507-510.

[92] X. Huang, D. Wang, Y. Hu, Y. Lu, Z. Guo, X. Kong and J. Sun (2008). Effect of sulfated astragalus polysaccharide on cellular infectivity of infectious bursal disease virus, Int. J. Biol. Macromol. 42, 166-171.

[93] F. Wang, G. Feng and K. Chen (2009). Burdock fructooligosaccharide induces resistance to tobacco mosaic virus in tobacco seedlings, Physiol. Mol. Plant Pathol. 74, 34-40.

[94] L.C. van Loon, M. Rep and C.M. Pieterse (2006). Significance of inducible defense-related proteins in infected plants, Annu. Rev. Phytopathol. 44, 135-162.

[95] W. Islam, S.U. Islam, M. Qasim and L. Wang (2017). Host-Pathogen interactions modulated by small RNAs, RNA Biology. 14, 891-904.

[96] R. Iglesias, L. Citores, A. Di Maro and J.M. Ferreras (2015). Biological activities of the antiviral protein BE27 from sugar beet (Beta vulgaris L.), Planta. 241, 421-433.

[97] S. Mansouri, M. Kutky and K.A. Hudak (2012). Pokeweed antiviral protein increases HIV-1 particle infectivity by activating the cellular mitogen activated protein kinase pathway, PloS one. 7, e36369.

[98] V. Aitbakieva and A. Domashevskiy (2015). Characterization of pokeweed antiviral protein (pap) isoforms and comparison of their enzymatic activities toward the tobacco etch virus RNA, FASEB J. 29, LB160.

[99] R. Di and N.E. Tumer (2015). Pokeweed antiviral protein: Its cytotoxicity mechanism and applications in plant disease resistance, Toxins. 7, 755-772.

[100] V.R. Aitbakieva and A.V. Domashevskiy (2016). Insights into the molecular antiviral mechanism of pokeweed protein from Phytolacca americana, Biochem Pharmacol (Los Angel). 5, 1000210. 
[101] Y. Lin, M. Hussain, P.B. Avery, M. Qasim, D. Fang and L. Wang (2016). Volatiles from plants induced by multiple aphid attacks promote conidial performance of Lecanicillium lecanii, PloS one. 11, e0151844.

[102] Y. Lin, M. Qasim, M. Hussain, K.S. Akutse, P.B. Avery, C.K. Dash and L. Wang (2017). The herbivoreinduced plant volatiles methyl salicylate and menthol positively affect growth and pathogenicity of entomopathogenic fungi, Sci. Rep. 7, 40494.

[103] P.V. Shivaprasad, H-M. Chen, K. Patel, D.M. Bond, B.A. Santos and D.C. Baulcombe (2012). A microRNA superfamily regulates nucleotide binding site-leucine-rich repeats and other mRNAs, The Plant Cell. 24, 859-874.

[104] K. Patel, R.B. Singh and D.K. Patel (2013). Medicinal significance, pharmacological activities, and analytical aspects of solasodine: A concise report of current scientific literature, J. Acute Dis. 2, 92-98.

[105] O. Erharuyi, A. Falodun and P. Langer (2014). Medicinal uses, phytochemistry and pharmacology of Picralima nitida (Apocynaceae) in tropical diseases: A review, Asian Pac. J. Trop. Med. 7, 1-8.

[106] V.M. Dembitsky (2005). Astonishing diversity of natural surfactants: 6. Biologically active marine and terrestrial alkaloid glycosides, Lipids. 40, 1081.

[107] X-H. Yan, J. Chen, Y-T. Di, X. Fang, J-H. Dong, P. Sang, Y-H. Wang, H-P. He, Z-K. Zhang and X-J. Hao (2010). Anti-tobacco mosaic virus (TMV) quassinoids from Brucea javanica (L.) Merr, J. Agric. Food Chem. 58, 1572-1577.

[108] W. Dhifi, S. Bellili, S. Jazi, N. Bahloul and W. Mnif (2016). Essential oils' chemical characterization and investigation of some biological activities: a critical review, Medicines. 3, 25.

[109] A.R. Bilia, C. Guccione, B. Isacchi, C. Righeschi, F. Firenzuoli and M.C. Bergonzi (2014). Essential oils loaded in nanosystems: a developing strategy for a successful therapeutic approach, Evid. Based Complement. Alternat. Med. 2014, Article ID 651593.

[110] A. Djilani and A. Dicko (2012). The therapeutic benefits of essential oils. In Nutrition, Well-Being and Health, InTech, 155-178.

[111] B. Teixeira, A. Marques, C. Ramos, N.R. Neng, J.M.F. Nogueira, J.A. Saraiva and M.L. Nunes (2013). Chemical composition and antibacterial and antioxidant properties of commercial essential oils, Ind. Crops Prod. 43, 587-595.

[112] K. Hüsnü, C. Başer and F. Demirci (2007). Chemistry of essential oils. In Flavours and Fragrances, Springer, 43-86.

[113] F. Bakkali, S. Averbeck, D. Averbeck and M. Idaomar (2008). Biological effects of essential oils-a review, Food Chem. Toxicol. 46, 446-475.

[114] E.W.C. Chan, E.Y. Soh, P.P. Tie and Y.P. Law (2011). Antioxidant and antibacterial properties of green, black, and herbal teas of Camellia sinensis, Pharmacognosy Res. 3, 266-272.

[115] N.C. Veitch and R.J. Grayer (2011). Flavonoids and their glycosides, including anthocyanins, Nat. Prod. Rep. 28, 1626-1695.

[116] C. Brunetti, M. Di Ferdinando, A. Fini, S. Pollastri and M. Tattini (2013). Flavonoids as antioxidants and developmental regulators: relative significance in plants and humans, Int. J. Mol. Sci. 14, 3540-3555.

[117] A.R. Khalatbary (2013). Olive oil phenols and neuroprotection, Nutr. Neurosci. 16, 243-249.

[118] W-Y. Huang, Y-Z. Cai and Y. Zhang (2009). Natural phenolic compounds from medicinal herbs and dietary plants: potential use for cancer prevention, Nutr. Cancer. 62, 1-20.

[119] A-N. Li, S. Li, Y-J. Zhang, X-R. Xu, Y-M. Chen and H-B. Li (2014). Resources and biological activities of natural polyphenols, Nutrients. 6, 6020-6047.

[120] A. Rodriguez-Mateos, C. Heiss, G. Borges and A. Crozier (2013). Berry (poly) phenols and cardiovascular health, J. Agric. Food Chem. 62, 3842-3851.

[121] X. Jia, Q. Meng, H. Zeng, W. Wang and H. Yin (2016). Chitosan oligosaccharide induces resistance to Tobacco mosaic virus in Arabidopsis via the salicylic acid-mediated signalling pathway, Sci. Rep. 6, 26144.

[122] H. Lu, X. Zhao, W. Wang, H. Yin, J. Xu, X. Bai and Y. Du (2010). Inhibition effect on tobacco mosaic virus and regulation effect on calreticulin of oligochitosan in tobacco by induced $\mathrm{Ca}^{2+}$ influx, Carbohydr. Polym. 82, 136-142.

[123] J. Yasuhara-Bell and Y. Lu (2010). Marine compounds and their antiviral activities, Antivir. Res. 86, 231240.

[124] M. Iriti and E.M. Varoni (2015). Chitosan-induced antiviral activity and innate immunity in plants, Environ. Sci. Pollut. Res. 22, 2935-2944. 
[125] M. Iriti and F. Faoro (2008). Abscisic acid is involved in chitosan-induced resistance to tobacco necrosis virus (TNV), Plant Physiol. Biochem. 46, 1106-1111.

[126] M. Iriti, M. Sironi, S. Gomarasca, A.P. Casazza, C. Soave and F. Faoro (2006). Cell death-mediated antiviral effect of chitosan in tobacco, Plant Physiol. Biochem. 44, 893-900.

[127] X. Zhao, X. She, Y. Du and X. Liang (2007). Induction of antiviral resistance and stimulary effect by oligochitosan in tobacco, Pestic. Biochem. Physiol. 87, 78-84.

[128] T. Teplyakova and T. Kosogova (2015). Fungal Bioactive Compounds with Antiviral Effect, J. Pharm. Pharmacol. 3, 357-371.

[129] M. Adnan, W. Zheng, W. Islam, M. Arif, Y.S. Abubakar, Z. Wang and G. Lu (2017). Carbon catabolite repression in filamentous fungi, Int. J. Mol. Sci. 19, 48.

[130] P.J. Seo, A-K. Lee, F. Xiang and C-M. Park (2008). Molecular and functional profiling of Arabidopsis pathogenesis-related genes: insights into their roles in salt response of seed germination, Plant Cell Physiol. 49, 334-344.

[131] N. Wang, J. Yang, J. Lu, Q. Qiao, T. Wu, X. Du, G. Bao and X. He (2014). A polysaccharide from Salvia miltiorrhiza Bunge improves immune function in gastric cancer rats, Carbohydr. Polym. 111, 47-55.

[132] N.A. Magarvey, J.M. Keller, V. Bernan, M. Dworkin and D.H. Sherman (2004). Isolation and characterization of novel marine-derived actinomycete taxa rich in bioactive metabolites, Appl. Environ. Microbiol. 70, 7520-7529.

[133] J. Prudhomme, E. McDaniel, N. Ponts, S. Bertani, W. Fenical, P. Jensen and K. Le Roch (2008). Marine actinomycetes: a new source of compounds against the human malaria parasite, PloS one. 3, e2335.

[134] Y. Han, Y. Luo, S. Qin, L. Xi, B. Wan and L. Du (2014). Induction of systemic resistance against tobacco mosaic virus by Ningnanmycin in tobacco, Pestic. Biochem. Physiol. 111, 14-18.

[135] D. Dan, W. Chunmei and W. Yuanhua (2006). Antiphytoviral action mechanism of Cytosinpeptidemycin's complexation chemical pesticide, J. Shenyang Agric. Univ. 37, 593-596.

[136] Y-H. Wang, Y-H. Wu, C-Y. Zhu and C-M. Du (2006). Studies on a new antiviral component of cytosinpeptidemycin, J. Shenyang Agric. Univ. 37, 44.

[137] G. Zhang, L. Han, G. Zhang, X. Zhang and J. Feng (2015). Purification and characterization of a novel glycoprotein from Streptomyces sp. ZX01, Int. J. Biol. Macromol. 78, 195-201.

[138] N.N. Azwanida (2015). A review on the extraction methods use in medicinal plants, principle, strength and limitation, Med. Arom. Plants. 4, 1000196.

[139] IIFOAM (2005). Norms for organic production and processing: IFOAM Basic Standards. Bonn, Germany: IFOAM. 148 pp.

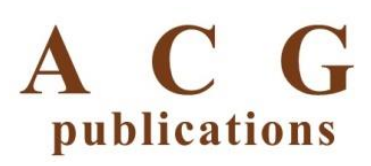

(C) 2018 ACG Publications 